\title{
Erratum to: Distribution of killer cell immunoglobulin-like receptors(KIR) and their HLA-C ligands in two Iranian populations
}

\author{
Susan E. Hiby • Maziar Ashrafian-Bonab • \\ Lydia Farrell • Richard M. Single • Francois Balloux • \\ Mary Carrington · Ashley Moffett • Zahra Ebrahimi
}

Published online: 9 March 2010

(C) Springer-Verlag 2010

\section{Erratum to: Immunogenetics}

\section{DOI: $10.1007 / \mathbf{s 0 0 2 5 1 - 0 0 9 - 0 4 0 8 - 5}$}

The original version of this article unfortunately contained a mistake. Dr. Zahra Ebrahimi was not listed among the authors.
The online version of the original article can be found under http://dx. doi.org/10.1007/s00251-009-0408-5.

\section{S. E. Hiby $(\bowtie) \cdot$ L. Farrell $\cdot$ A. Moffett}

Department of Pathology, University of Cambridge,

Tennis Court Road,

Cambridge CB2 1QP, UK

e-mail: seh1002@cam.ac.uk

\section{A. Moffett \\ e-mail: am485@cam.ac.uk}

M. Ashrafian-Bonab

Department of Biological Sciences, University of Portsmouth, King Henry Building, King Henry 1 Street,

Portsmouth, UK

\section{R. M. Single}

Department of Mathematics and Statistics, University of Vermont, Burlington, VT, USA

\section{F. Balloux}

Department of Infectious Disease Epidemiology,

Imperial College Faculty of Medicine,

MRC Centre for Outbreak Analysis and Modelling,

St. Mary's Campus, Norfolk Place,

London W2 1PG, UK

M. Carrington

Cancer and Inflammation Program,

Laboratory of Experimental Immunology, SAIC-Frederick Inc.,

NCI-Frederick,

Frederick, MD, USA

\section{Z. Ebrahimi}

Infertility Treatment Highly Specialized Centre,

Iranian Academic Centre for Education Culture \& Research,

Shabnam Street, 1 Eisar Square,

Qom, Iran 